\title{
PERENCANAAN BISNIS MERCHANDISE RESMI UNIVERISTAS ABC DENGAN MENGGUNAKAN TIMMONS MODEL
}

\author{
Annisa Maharani Suyono ${ }^{1}$, Obsatar Sinaga ${ }^{2}$, Tezza Adriansyah Anwar ${ }^{3}$ \\ Program Studi Magister Manajemen, Fakultas Bisnis dan Manajemen, Universitas Widyatama 1,2,3 \\ Jalan Cikutra No.204 A, Bandung \\ annisa.maharani@widyatama.ac.id ${ }^{1}$, obsatar.sinaga@widyatama.ac.id $^{2}, \underline{\text { Tezza.anwar@widyatama.ac.id }}^{3}$
}

\begin{abstract}
Abstrak
Citra perusahaan merupakan hal yang penting karena berpengaruh terhadap keputusan konsumen dalam membeli produk. Sama halnya pada perguruan tinggi atau universitas, universitas merupakan institusi dimana perguruan tinggi mencari mahasiswa seperti perusahaan yang mencari konsumen. Salah satu banding university yang dapat dilakukan adalah melalui merchandise. Dalam hal ini, Universitas ABC berencana untuk mendirikan toko merchandise resmi sebagai salah satu usaha untuk menciptakan mind brand atau memasukan brand kampus kepada setiap hati orang yang melihat dan juga menaikan rasa ingin tahu setiap orang mengenai Universitas ABC. Saat ini, jumlah target pasar mencapai 11.485 orang, terdiri dari $96 \%$ mahasiswa dan $4 \%$ dosen serta karyawan. Jumlah tersebut merupakan peluang pasar yang cukup tinggi untuk toko merchandise resmi Universitas ABC. Penelitian ini menggunakan teknik pengumpulan data wawancara semi terstruktur dengan tim pendiri dan pengelola serta dokumentasi dengan mengumpulkan data internal perusahaan yang telah tersedia yang berkaitan dengan toko merchandise. Pada penelitian ini akan dilakukan kelayakan usaha menggunakan kriteria kewirausahaan menurut Timmons. Secara teori, Model Timmons dapat dijadikan sebagai pedoman untuk mencapai kesuksesan dalam berwirausaha dengan memperhatikan faktor peluang, sumber daya dan tim. Posisi bisnis menurut hasil EFAS (0.93) dan IFAS (0.79) berada pada kuadran I yang mendukung strategi agresif. Bisnis toko merchandise resmi ini layak dan termasuk dalam kondisi bisnis yang berpotensi tinggi untuk dilaksanakan dan dikembangkan menurut hasil quick screen kriteria Timmons. Hasil perhitungan proyeksi keuangan yang
\end{abstract}

memperoleh kategori potensi tinggi yaitu, IRR sebesar 84\%, Gross Profit Margin sebesar 32\%, Net Profit Margin sebesar 20\% dan ROI sebesar 48\%.

Kata Kunci:

mind brand, merchandise, model Timmons

\begin{abstract}
Company image is important because it influences consumer decisions in buying products. Similarly, in universities which are institutions where universities look for students, like companies that look for consumers. One of the university's appeals that can be done is through merchandise. In this case, $A B C$ University plans to establish an official merchandise store as an effort to create a brand mind or incorporate a campus brand into every heart of people who see and also raise everyone's curiosity about $A B C$ University. At present, the target market reaches 11,485 people, consisting of $96 \%$ students and $4 \%$ lecturers and employees. This amount represents a high enough market opportunity for $A B C$ University official merchandise stores. This study uses a semi-structured interview data collection technique with the founding and managing team as well as documentation by collecting available internal company data relating to the merchandise shop. In this study, business feasibility will be carried out using the entrepreneurial criteria according to Timmons. In theory, the Timmons Model can be used as a guide to achieving success in entrepreneurship by taking into account opportunities, resources and team factors. Business positions according to the results of EFAS (0.93) and IFAS (0.79) are in quadrant I which supports an aggressive strategy. The official merchandise shop business is feasible and
\end{abstract}

Annisa Maharani Suyono, Obsatar Sinaga, Tezza Adriansyah Anwar 
includes high-potential business conditions to be implemented and developed according to the results of Timmons' quick screen criteria. The results of the calculation of financial projections that obtain high potential categories, namely, IRR of $84 \%$, Gross Profit Margin by 32\%, Net Profit Margin by 20\% and ROI by $48 \%$.

Keywords:

mind brand, merchandise, Timmons model

\section{Pendahuluan}

Branding Image merupakan salah satu hal yang penting dilakukan oleh sebuah perusahaan. Citra perusahaan yang melekat pada hati konsumen merupakan salah satu faktor yang mempengaruhi keputusan mereka dalam membeli produk yang dihasilkan oleh perusahaan. Sama halnya dengan perguruan tinggi yang merupakan institusi, dimana perguruan tinggi tentunya mencari mahasiswa yang dianalogikan mirip dengan perusahaan yang mencari pelanggan. Tentunya Universitas membutuhkan manajemen marketing yang handal untuk membantu membangun citra universitas atau branding university. Untuk saat ini, persaingan antara perguruan tinggi semakin pesat. Tidak hanya Perguruan Tinggi Swasta (PTS) tetapi Perguruan Tinggi Negeri (PTN) pun harus melakukan branding university untuk meningkatkan dan mempertahankan eksistensinya di dunia pendidikan dan dimata masyarakat.

Branding University yang dapat dilakukan oleh PTS ataupun PTN ialah dengan cara memperbanyak publikasi ilmiah, mengikuti konferensi tingkat nasional dan internasional, meningkatkan kualitas pendidikan, dan lain-lain. Tidak hanya fokus pada hal itu, salah satu upaya yang dapat dilakukan untuk mendukung branding university adalah dengan menggunakan media merchandise. Merchandise tak hanya sebatas manampilkan logo perusahaan semata. Lebih dari itu, merchandise adalah media pengingat bagi audiens yang memiliki manfaat dan dapat digunakan dalam kegiatan sehari-hari. Di Indonesia saat ini masih sangat sedikit universitas yang menggunakan merchandise resmi untuk memperluas jangkauan agar dikenal oleh masyarakat. Berbeda dengan universitas di luar negeri yang sangat peduli dengan branding university menggunakan merchandise. Bahkan mereka memiliki toko yang besar yang biasanya bersatu dengan toko buku dan keperluan lainnya.
Membangun citra dengan menggunakan media merchandise ini merupakan salah satu upaya yang akan dilakukan oleh Universitas ABC. Merchandise yang akan dibuat merupakan merchandise resmi yang menjadi visual identitas bagi Universitas ABC. Untuk mendirikan bisnis ini tentunya perlu perencanaan yang matang agar berjalan dengan baik. Penulis akan melakukan penelitian terhadap perencanaan bisnis tersebut dengan menggunakan kriteria kewirausahaan Timmons yang berdasarkan aspek-aspek lingkungan bisnis, pemasaran, sumber daya manusia, operasional dan keuangan, maka perencanaan bisnis toko merchandise tersebut akan diteliti dalam penelitian ini.

\section{KAJIAN LITERATUR}

Menurut Timmons dan Spinneli (2007), proses kewirausahaan dimulai dari peluang, didukung oleh sumber daya, dan diseimbangkan oleh tim. Karakteristik peluang yang baik dilihat dari tiga hal, yaitu permintaan pasar (market demand), struktur dan ukuran pasar (market structure and size), dan analisis selisih (margin analysis). Sumber daya yang dibutuhkan dalam proses kewirausahaan meliputi keuangan, aset, manusia, dan rencana bisnis. Tim merupakan faktor penyeimbang dalam proses kewirausahaan, karena tim yang baik akan mampu mengelola keseimbangan antara peluang dan sumber daya. Dari analisis dan elaborasi yang dilakukan Timmons terhadap hasil penelitian yang dilakukan selama tiga decade oleh Harvard Bussiness School, proses kewirausahaan digambarkan sebagai tiga buah bola kekuatan yang harus diramu, sehingga terjadi kesesuaian dan keseimbangan. Timmons selanjutnya menggambarkan interaksi ketiga kekuatan tersebut dengan Gambar 1 di bawah ini.

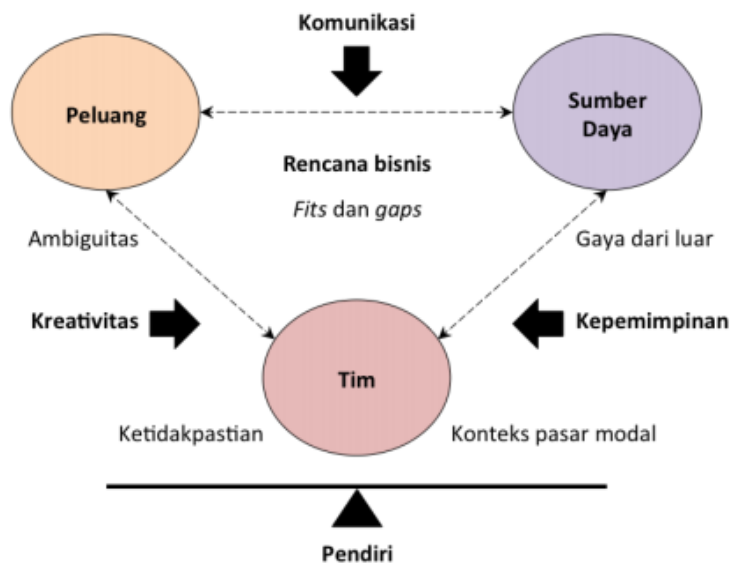

Keberlanjutan: untuk Lingkungan, Komunitas, dan Masyarakat

Annisa Maharani Suyono, Obsatar Sinaga, Tezza Adriansyah Anwar Jurnal Ilmiah Teknologi Informasi Terapan Volume 5, No 2, 15 April 2019 


\section{Gambar 1 Bagan Proses Kewirausahaan Timmons Model}

Dari Gambar 1 di atas, Timmons menganalisis bahwa bentuk, ukuran, dan dalamnya peluang usaha menentukan bentuk, ukuran dan dalamnya kondisi sumber daya dan tim. Hubungan antara ketiga kekuatan bagan Timmons harus diwarnai oleh konsep kesesuaian dan keseimbangan. Dengan demikian, tugas wirausahawan dan timnya adalah meramu semua faktor yang ada sehingga terjadi suatu keseimbangan. Dalam artian, dia harus bisa menguasai keadaan sehingga bisa mencapai keberhasilan usaha.

\section{PENGOLAHAN DATA}

\section{Analisis SWOT dan Timmons Model}

Berdasarkan hasil analisis wawancara mengenai aspek Model Timmons Model diatas, peneliti dapat mengidentifikasi kekuatan, kelemahan, peluang dan ancaman yang dihadapi. Identifikasi tersebut dapat dilihat pada Tabel 1 di bawah ini:

Tabel 1 Matriks Identifikasi SWOT \& Timmons Model

\begin{tabular}{|c|c|c|c|}
\hline $\begin{array}{r}\text { Timmons } \\
\text { SWOT }\end{array}$ & $\begin{array}{c}\text { Peluang Usaha } \\
\text { (Opportunity) }\end{array}$ & $\begin{array}{c}\text { Sumber Daya } \\
\text { (Resources) }\end{array}$ & $\begin{array}{c}\text { Tim } \\
\text { (Team) }\end{array}$ \\
\hline $\begin{array}{l}\text { Kekuatan } \\
\text { (Strength) }\end{array}$ & $\begin{array}{llr}\text { - } & \text { Produk } & \text { Resmi } \\
& \text { Universitas ABC } & \\
\text { - } & \text { Desain Unik } & \text { dan } \\
& \text { Menarik } & \\
\text { - } & \text { Produk } & \text { Mudah } \\
& \text { Didapatkan } & \end{array}$ & $\begin{array}{l}\text { - Kualitas Produk yang } \\
\text { Baik } \\
\text { - Harga Terjangkau } \\
\text { - Modal Usaha Tanpa } \\
\text { Pinjaman }\end{array}$ & $\begin{array}{ll}\text { - Dikelola } & \text { oleh Tim } \\
\text { Adhoc } & \text { Universitas } \\
\text { ABC } & \end{array}$ \\
\hline $\begin{array}{l}\text { Kelemahan } \\
\text { (Weakness) }\end{array}$ & $\begin{array}{l}\text { - Pasar Terbatas } \\
\text { - Masih berbentuk offline } \\
\text { store }\end{array}$ & $\begin{array}{ll}\text { - } & \text { Edukasi Market } \\
\text { - Tidak Memiliki Tim } \\
\text { Desain Khusus } \\
\text { - Media promosi belum } \\
\text { efektif }\end{array}$ & $\begin{array}{l}\text { - Sumber } \\
\text { Manusia yang masih } \\
\text { kurang }\end{array}$ \\
\hline $\begin{array}{c}\text { Peluang } \\
\text { (Opportunity) }\end{array}$ & $\begin{array}{l}\text { - Produksi Produk Special } \\
\text { Event } \\
\text { - Loyalitas Terhadap } \\
\text { Universitas } \\
\end{array}$ & - Lokasi yang strategis & $\begin{array}{l}\text { - Bekerja sama dengan } \\
\text { vendor }\end{array}$ \\
\hline $\begin{array}{c}\text { Ancaman } \\
\text { (Threat) }\end{array}$ & $\begin{array}{l}\text { - Pesaing yang lebih dulu } \\
\text { menjual produk dengan } \\
\text { menggunakan visual } \\
\text { identitas Universitas } \\
\text { tetapi tidak resmi. } \\
\text { - Daya beli mahasiswa } \\
\text { terhadap merchandise } \\
\text { resmi rendah. }\end{array}$ & $\begin{array}{l}\text { - Ketidakstabilan Kualitas } \\
\text { dari Vendor } \\
\text { - Harga bahan baku yang } \\
\text { tiba-tiba naik dan } \\
\text { mempengaruhi biaya } \\
\text { produksi }\end{array}$ & $\begin{array}{l}\text { - Rentan Kehilangan } \\
\text { Karyawan }\end{array}$ \\
\hline
\end{tabular}

Kinerja perusahaan dapat ditentukan oleh kombinasi faktor internal dan faktor ekstenal. Kedua faktor tersebut harus dipertimbangkan dalam análisis SWOT. SWOT adalah singkatan dari lingkungan Internal Strengths dan Weakness serta lingkungan Ekstenal Opportunities dan Threats yang dihadapi di dunia bisnis. Analisis SWOT membandingkan antara faktor eksternal dan faktor internal dari sebuah bisnis. Matriks SWOT memiliki 4 kuadran untuk mengetahui posisi bisnis perusahaan untuk menentukan strategi bisnis yang akan digunakan oleh perusahaan. Berikut ini adalah penjelasan untuk penentuan dan perbandingan faktor eksternal dan internal bisnis toko merchandise ini.

\section{Eksternal Factor Analysis Summary (EFAS)}

Sebelum melakukan proses perencanaan strategi, peneliti harus menganalisis faktor eksternal untuk 
mengetahui berbagai kemungkinan peluang dan ancaman dari toko merchandise. Faktor-faktor peluang dan ancaman didapat berdasarkan hasil wawancara dari informan yaitu Tim Adhoc.

Penentuan bobot dan peringkat pada Tabel 2 dilakukan oleh informan kemudian dianalisa oleh peneliti sesuai dengan kondisi dari bisnis ini. Bobot masing-masing faktor dari peluang dan ancaman diberi nilai mulai dari 1.0 (sangat penting) sampai dengan 0.0 (tidak penting). Pemberian peringkat untuk faktor peluang bersifat positif (peluang yang semakin besar diberi rating +4 , tetapi jiga peluangnya kecil diberi rating +1). Pemberian rating ancaman adalah kebalikannya. Penentuan skor bobot dilakukan dengan cara mengkalikan bobot setiap variabel dengan peringkat tiap variabel.

Kemudian jumlahkan hasil skor bobot pada faktor peluang dan ancaman lalu hitung selisih dari kedua faktor tersebut. Nilai peluang pada Tabel 2 menunjukan bahwa peluang usaha toko merchandise 0.93 lebih besar dari ancaman yang akan terjadi.

Tabel 2 Eksternal Factor Analysis Summary (EFAS)

\begin{tabular}{|c|c|c|c|c|}
\hline Faktor Eksternal & Bobot (B) & Peringkat $(\mathrm{P})$ & $\begin{array}{c}\text { Skor Bobot } \\
(\text { BxP) }\end{array}$ & Keterangan \\
\hline \multicolumn{5}{|l|}{ OPportunities $(\mathrm{O})$} \\
\hline 1. Produksi Produk Special Event & 0.11 & 4 & 0.44 & Peluang Tinggi \\
\hline 2. Loyalitas Terhadap Almamater & 0.11 & 4 & 0.44 & Peluang Tinggi \\
\hline 3. Lokasi yang Strategis & 0.12 & 4 & 0.48 & Peluang Sangat Tinggi \\
\hline 4. Bekerjasama dengan Vendor & 0.08 & 3 & 0.24 & Peluang Cukup Tinggi \\
\hline 5. Target Pasar Meningkat & 0.09 & 3 & 0.27 & Peluang Cukup Tinggi \\
\hline \multicolumn{2}{|l|}{ Sub Total } & & 1.87 & \\
\hline \multicolumn{5}{|l|}{ Threath $(\mathrm{T})$} \\
\hline 1. Pesaing & 0.1 & 3 & 0.3 & Ancaman Tinggi \\
\hline 2. Ketidakstabilan Kualitas & 0.12 & 1 & 0.12 & Ancaman Tinggi \\
\hline 3. Harga Bahan Baku Meningkat & 0.1 & 1 & 0.1 & Ancaman Tinggi \\
\hline 4. Daya Beli Konsumen & 0.09 & 2 & 0.18 & Ancaman Dapat Diatasi \\
\hline 5. Rentan Kehilangan Karyawan & 0.08 & 3 & 0.24 & Ancaman Dapat Diatasi \\
\hline \multicolumn{2}{|l|}{ Sub Total } & & 0.94 & \\
\hline Total & 1 & & 0.93 & \\
\hline
\end{tabular}

\section{Internal Factor Analysis Summary (IFAS)}

Analisis faktor strategis internal dilakukan dengan cara yang sama seperti EFAS. Analisis faktor strategis internal meliputi kekuatan dan kelemahan dari toko tersebut. Faktor-faktor kekuatan dan kelemahan didapat berdasarkan hasil wawancara dari informan yaitu Tim Adhoc. Penentuan bobot pada Tabel 3 dilakukan oleh informan kemudian dianalisa oleh peneliti sesuai dengan kondisi dari bisnis UTama Store. Bobot masing-masing faktor dari kekuatan dan kelemahan diberi nilai mulai dari 1.0 (paling penting) sampai dengan 0.0 (tidak penting). Variabel yang bersifat positif (seluruh varibel pada faktor kekuatan) diberi rating mulai dari +1 sampai dengan +4 (sangat baik), sedangkan untuk variabel yang bersifat negatif (seluruh variabel pada faktor kelemahan) diberi rating sebaliknya. Penentuan skor bobot dilakukan dengan cara mengkalikan bobot tiap variabel dengan peringkat tiap variabel. Kemudian jumlahkan hasil skor bobot pada faktor kekuatan dan kelemahan lalu hitung selisih dari kedua faktor tersebut. Nilai kekuatan pada Tabel 3 menunjukan bahwa kekuatan dari bisnis toko

Annisa Maharani Suyono, Obsatar Sinaga, Tezza Adriansyah Anwar 
merchandise 90.93 lebih besar dari kelemahan yang

dimiliki oleh perusahaan.

Tabel 3 Internal Factor Analysis Summary (IFAS)

\begin{tabular}{|c|c|c|c|c|}
\hline Faktor Internal & $\begin{array}{l}\text { Bobot } \\
\text { (B) }\end{array}$ & $\begin{array}{l}\text { Peringkat } \\
\text { (P) }\end{array}$ & $\begin{array}{c}\text { Skor Bobot } \\
\text { (BxP) }\end{array}$ & Keterangan \\
\hline \multicolumn{5}{|c|}{ Strengths (S) } \\
\hline 1. Produk Resmi Universitas & 0.07 & 3 & 0.21 & Baik \\
\hline 2. Desain Unik dan Menarik & 0.08 & 3 & 0.24 & Baik \\
\hline 3. Kualitas Produk yang Baik & 0.1 & 4 & 0.4 & Sangat Baik \\
\hline 4. Harga Terjangkau & 0.1 & 4 & 0.4 & Sangat Baik \\
\hline 5. Produk Mudah Didapatkan & 0.06 & 3 & 0.18 & Cukup Baik \\
\hline 6. Modal Usaha Tanpa Pinjaman & 0.05 & 2 & 0.1 & Cukup Baik \\
\hline 7. Dikelola Langsung Oleh Yayasan & 0.05 & 2 & 0.1 & Cukup Baik \\
\hline Sub Total & & & 1.53 & \\
\hline \multicolumn{5}{|c|}{ Weakness $(\mathrm{W})$} \\
\hline 1. Edukasi Market & 0.07 & & 0.14 & Menjadi perhatian tim manajemen \\
\hline 2. Tidak Memiliki Tim Desain & 0.06 & 3 & 0.18 & Masih dapat diatasi \\
\hline 3. Pasar Terbatas & 0.04 & 4 & 0.16 & Masih dapat diatasi \\
\hline 4. Masih Berbentuk Offline Store & 0.09 & 1 & 0.09 & Menjadi perhatian tim manajemen \\
\hline 5. Media Promosi Belum Efektif & 0.09 & 1 & 0.09 & Menjadi perhatian tim manajemen \\
\hline 6. SDM yang Masih Kurang & 0.08 & 1 & 0.08 & Menjadi perhatian tim manajemen \\
\hline 7. Sistem Penjualan Masih Manual & 0.06 & 2 & 0.12 & Masih dapat diatasi \\
\hline Sub Total & & & 0.74 & \\
\hline Total & 0.94 & & 0.79 & \\
\hline
\end{tabular}

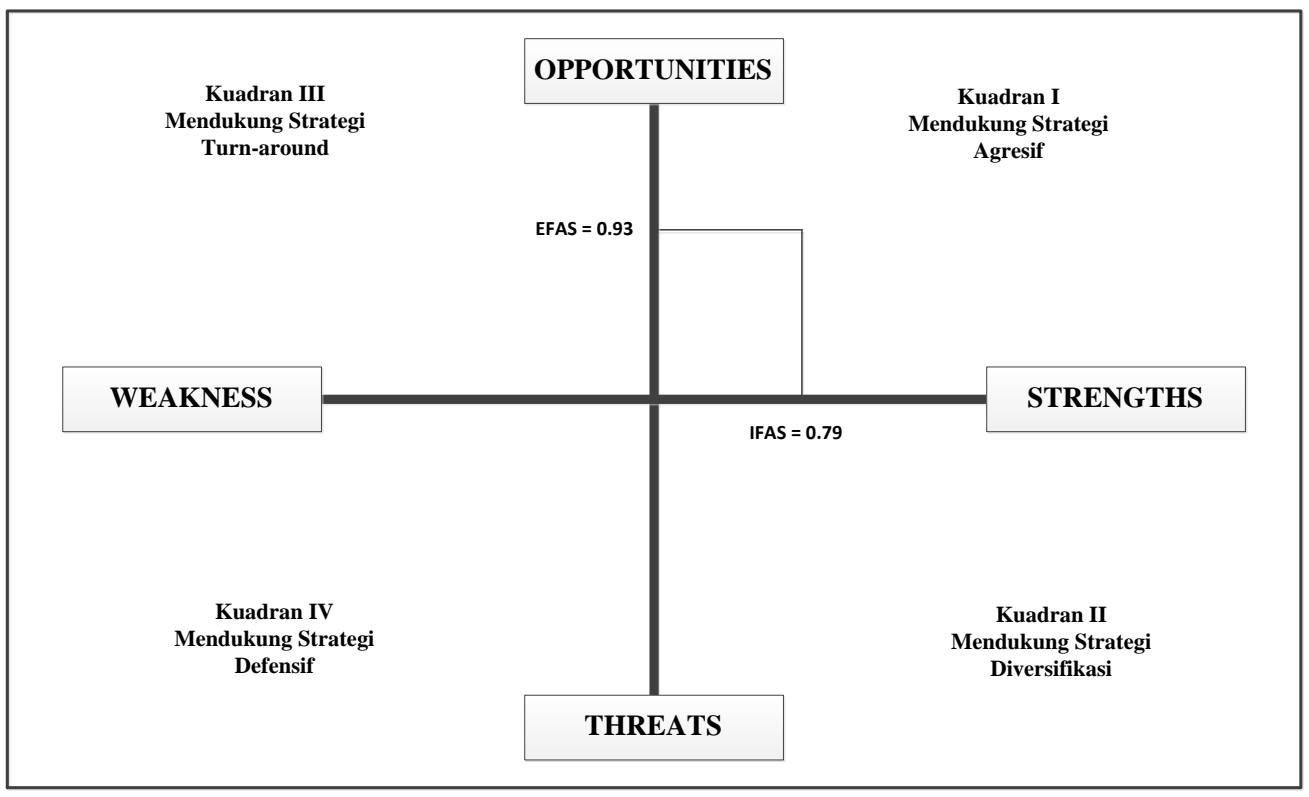

Gambar 2 Diagram Matriks SWOT

Annisa Maharani Suyono, Obsatar Sinaga, Tezza Adriansyah Anwar

Jurnal Ilmiah Teknologi Informasi Terapan

Volume 5, No 2, 15 April 2019 
Hasil penelitian EFAS dan IFAS kemudian dimasukan kedalam diagram matriks SWOT dengan 4 indikator seperti pada Gambar 2 Posisi bisnis merchandise pada gambar tersebut menunjukan kuadran I, ini merupakan situasi yang sangat menguntungkan. Bisnis ini dapat memanfaatkan peluang yang ada. Strategi yang harus diterapkan dalam kondisi ini adalah mendukung kebijakan pertumbuhan yang agresif (Growth Oriented Strategy).

\begin{tabular}{|c|c|c|}
\hline $\begin{array}{r}\text { Interlal Strategic Factors } \\
\text { Analysis Summary } \\
\text { (IFAS) }\end{array}$ & \begin{tabular}{|l|} 
Strengthl $(\mathrm{S})$ \\
S1 Produk Resmi Universitas \\
S2 Desain Unik dan Menarik \\
S3 Kualitas Produk yang Baik \\
S4 Harga Terjangkau \\
S5 Produk Mudah Didapatkan \\
S6 Modal Usaha Tanpa Pinjaman \\
S7 Dikelola oleh Tim Adhoc
\end{tabular} & $\begin{array}{l}\text { Weakness (W) } \\
\text { W1 Edukasi Market } \\
\text { W2 Tidak Memiliki Tim Desain } \\
\text { W3 Pasar Terbatas } \\
\text { W4 Masih berbentuk Offline Store } \\
\text { W5 Media Promosi Belum Efektif } \\
\text { W6 Organisasi yang belum jelas } \\
\text { W7 Sistem Penjualan Manual }\end{array}$ \\
\hline Opportunities (O) & STRATEGI SO & STRATEGI WO \\
\hline $\begin{array}{l}\text { O1 Produksi Produk Special Event } \\
\text { O2 Loyalitas Terhadap Almamater } \\
\text { O3 Lokasi yang Strategis } \\
\text { O4 Bekerjasama dengan Vendor } \\
\text { O5 Target Pasar Meningkat }\end{array}$ & $\begin{array}{l}\text { SO1: Melakukan inovasi pada } \\
\text { produk dan desain (S1, S2, S3, O4, } \\
\text { O5). } \\
\text { SO2: Menjalin kerjasama dengan } \\
\text { vendor yang berkualitas dan } \\
\text { terpercaya. (S3, S4, O4) } \\
\text { SO3 : Desain dan fasilitas store yang } \\
\text { menarik (S6, O3) }\end{array}$ & $\begin{array}{l}\text { WO1 : Gencar melakukanpromos } \\
\text { secara offlinemaupun online (W1, } \\
\text { W5, O3, O5) } \\
\text { WO2: Membuat online store (W4, } \\
\text { O5) } \\
\text { WO3 : Membuat sistem aplikasi } \\
\text { penjualan berbasis web (W7, O1, } \\
\text { O2, O5) }\end{array}$ \\
\hline Threats (T) & STRATEGI ST & STRATEGI WT \\
\hline $\begin{array}{l}\text { T1 Pesaing } \\
\text { T2 Ketidakstabilan Kualitas dar } \\
\text { Vendor } \\
\text { T3 Harga Bahan Baku Meningkat } \\
\text { T4 Daya Beli Konsumen Rendah } \\
\text { T5 Rentan Kehilangan Karyawan }\end{array}$ & $\begin{array}{l}\text { ST1 : Menja dikan pesaing sebagai } \\
\text { mitra usaha (S3, T1) } \\
\text { ST2 : Program giveaway dan sale } \\
\text { produk (S2, S4, T4) } \\
\text { ST3 : Cost Push Pricing Method } \\
\text { (S6, T4) }\end{array}$ & $\begin{array}{l}\text { WT1 : Memperbaiki Organisasi } \\
\text { Perusahaan(W6, T5) } \\
\text { WT2: Online Marketing (W3, W4, } \\
\text { W7, T4) } \\
\text { WT3 : Membuat Aturan-aturan \& } \\
\text { SOP Perusahaan(W6, T1, T2, T3) }\end{array}$ \\
\hline
\end{tabular}

Gambar 3 Matriks TOWS merchandise Universitas ABC

\section{Analisis Kelayakan Bisnis}

Analisis kelayakan bisnis UTama Store dilakukan dengan menggunakan kriteria-kriteria dari Timmons. Pada Tabel 7 merupakan Quick Screen kriteria Timmons untuk bisnis UTama Store.

Gambaran hasil dari quick screen kriteria Timmons untuk bisnis UTama Store yang telah diuraikan pada Tabel 7 menunjukan bahwa sekitar $75 \%$ bisnis UTama Store ini memiliki potensi yang tinggi untuk dijalankan sebagai salah satu unit usaha Universitas Widyatama. Target pasar yang cukup besar dan lokasi yang sangat strategis menjadi nilai tambah untuk bisnis tersebut. Kekurangan dalam segi pengembalian investasi dan peningkatan pertumbuhan pasar yang rendah dapat disiasati dengan menggunakan strategi hasil dari análisis SWOT. Begitu juga dengan keinginan dan kebutuhan konsumen yang belum teridentifikasi, dapat segeradiketahui dengan melakukan test pasar. Dengan menjalankan strategi dari hasil análisis SWOT diharapkan bisnis ini akan berjalan dengan baik

Annisa Maharani Suyono, Obsatar Sinaga, Tezza Adriansyah Anwar 
Tabel 4 Quick Screen kriteria Timmons bisnis merchandise

\begin{tabular}{|c|c|c|c|c|}
\hline & I. Marke & nd Margin Related Issues & & \\
\hline \multirow{2}{*}{ Kriteria } & \multicolumn{2}{|c|}{ Timmons } & \multicolumn{2}{|c|}{ Merchandise Univ.ABC } \\
\hline & Potensi Tinggi & Potensi Rendah & Hasil & Penilaiam \\
\hline $\begin{array}{c}\text { Kebutuhan dan Keinginan } \\
\text { Konsumen }\end{array}$ & Teridentifikasi & Tidak teridentifikasi & $\begin{array}{c}\text { Belum } \\
\text { Teridentifikasi }\end{array}$ & Potensi Rendah \\
\hline Konsumen & $\begin{array}{c}\text { Terjangkau dan } \\
\text { menerima } \\
\text { produk/jasa } \\
\end{array}$ & Tidak / sulit dijangkau & Terjangkau & Potensi Tinggi \\
\hline Payback Period & $<1$ tahun & $>3$ tahun & 2 Tahun 9 Bulan & Potensi Rendah \\
\hline Nilai Tambah & IRR $40 \%+$ & IRR $<20 \%$ & $\mathrm{IRR}=84 \%$ & Potensi Tinggi \\
\hline $\begin{array}{c}\text { Tingkat Pertumbuhan } \\
\text { Pasar } \\
\end{array}$ & $20 \%$ & $<20 \%$ & Menurun & Potensi Rendah \\
\hline Gross Profit Margin & $>40 \%$ & $<20 \%$ & $32 \%$ & Potensi Tinggi \\
\hline \multicolumn{5}{|c|}{ 2. Competitive Advantage } \\
\hline \multirow{2}{*}{ Kriteria } & \multicolumn{2}{|c|}{ Timmons } & \multicolumn{2}{|c|}{ Merchandise Univ.ABC } \\
\hline & Potensi Tinggi & Potensi Rendah & Hasil & Penilaiam \\
\hline $\begin{array}{c}\text { Biaya Tetap dan Tidak } \\
\text { Tetap }\end{array}$ & Tinggi & Rendah & Tinggi & Potensi Tinggi \\
\hline $\begin{array}{l}\text { Tingkat Pengendalian } \\
\text { Harga dan Biaya }\end{array}$ & Tinggi & Rendah & Tinggi & Potensi Tinggi \\
\hline Jaringan & Luas dan kuat & Sempit & Kuat dan Luas & Potensi Tinggi \\
\hline \multicolumn{5}{|c|}{ 3. Value Creation and Realization Issues } \\
\hline \multirow{2}{*}{ Kriteria } & \multicolumn{2}{|c|}{ Timmons } & \multicolumn{2}{|c|}{ Merchandise Univ.ABC } \\
\hline & Potensi Tinggi & Potensi Rendah & Hasil & Penilaiam \\
\hline Net Profit Margin & $10-15 \%$ atau lebih & $<5 \%$ & $20 \%$ & Potensi Tinggi \\
\hline Waktu Arus Kas Positif & $<2$ tahun & $>3$ tahun & Tahun ke-1 & Potensi Tinggi \\
\hline Return Of Investment & $40-70 \%$ atau lebih & $<20 \%$ & $48 \%$ & Potensi Tinggi \\
\hline
\end{tabular}

\section{KESIMPULAN DAN SARAN}

Berikut ini adalah kesimpulan dari hasil penelitian yang telah dibahas:

1. Berdasarkan hasil analisis SWOT dimana analisis yang dilakukan untuk mengetahui kekuatan, kelemahan, peluang dan ancaman yang ada pada bisnis merchandise Universitas ABC, posisi bisnis menurut hasil EFAS (0.93) dan IFAS (0.79) berada pada kuadran I yang mendukung strategi agreasif.

2. Perencanaan bisnis merchandise Universitas ABC mempunyai potensi tinggi sebesar $75 \%$ dan layak untuk diteruskan sebagai implementasi bisnis menurut kriteria Timmons. Potensi yang tinggi tersebut dipengaruhi oleh proyeksi arus kas yang baik dari perusahaan. Hasil perhitungan proyeksi keuangan yaitu, IRR sebesar 84\%, Gross Profit Margin sebesar 32\%, Net Profit Margin sebesar 20\% dan ROI sebesar $48 \%$.

Berdasarkan penelitian yang dilakukan, saransaran yang dapat diberikan penulis adalah sebagai berikut:

1. Struktur organisasi perlu diperbaiki untuk mendukung kelangsungan bisnis merchandise Universitas $\mathrm{ABC}$ dengan membuat struktur 
2. organisasi yang mengakomodasi keperluan tugas dan tanggung jawab dari suatu jabatan yang memang harus ada pada kebutuhan bisnis tersebut.

3. Terkait dengan hasil dari quick screen kriteria Timmons dengan hasil positif yang berpotensi tinggi untuk menjalankan bisnis, perlu ditindaklanjuti dengan analisis yang lebih mendalam terhadap keinginan dan kebutuhan dari pasar untuk memperbaiki kondisi bisnis merchandise Universitas ABC

4. Kondisi pasar $95 \%$ adalah mahasiswa Universitas $\mathrm{ABC}$, dimana daya beli mereka sangat dipengaruhi oleh faktor psikografi yaitu status sosial, personalitas dan gaya hidup. Hal ini menjadi tantangan untuk membuat programprogram menarik untuk dapat menarik perhatian konsumen.

\section{REFERENSI}

Kotler, P., \& Amstrong, G. (2012). Manajemen Pemasaran. Bandung: Alfabeta.

Rangkuti, Freedy. 2002. Analisis SWOT: Teknik Membedah Kasus Bisnis - Reorientasi Konsep Perencanaan Strategis untuk Menghadapi Abad 21, Jakarta: PT. Gramedia Pustaka Utama.

Sugiyono., 2014. Metode Penelitian Kuantitatif, Kualitatif, dan $R \& D$. Bandung: Alfabeta.

Sunarya, PO Abas dkk. 2011. Kewirausahaan: Pengelolaan dan Pengembangan Entrepreneurship IT-Preneurship, Kewirausahaan di Bidang Teknologi Informasi, Teori dan Praktik Pengelolaan Kewirausahaan Dilengkapi dengan Kasus. Yogyakarta: ANDI.

Kasmir dan Jakfar. 2003. Studi Kelayakan Bisnis Edisi ke-2. Jakarta: Prenada Media Group.

Rangkuti, Freedy. 2005. Business Plan : Teknik Membuat Perencanaan Bisnis dan Analisis Kasus, Jakarta: PT. Gramedia Pustaka Utama. 